\title{
A Geographic Information System for Managing and Mapping Irrigation Infrastructure
}

\author{
Rachmat Wahid Saleh Insani ${ }^{1)^{*}}$, Syarifah Putri Agustini ${ }^{2)}$ \\ 12) Universitas Muhammadiyah Pontianak, Indonesia \\ ${ }^{1)}$ rachmat.wahid@unmuhpnk.ac.id, 2)agustini.putri@unmuhpnk.ac.id
}

\author{
Submitted : Sep 6, 2020 | Accepted : Oct 12, 2020 | Published : Oct 12, 2020
}

\begin{abstract}
Indonesia is one of the world's major agricultural nation which offers wide diversity of tropical products and agricultural commodities produced in substantial number of agricultural areas. Some of these areas are equipped with irrigation infrastructures which delivers water management throughout the land. Irrigation helps grow agricultural crops, maintain landscapes, and revegetation disturbed soils in dry areas. Water resources are finite while cyclic droughts on agricultural areas affecting the amount of water remains, thus creating unbalanced water demand and supply. Therefore, building an effective plan and management for irrigation infrastructure must be conducted using reliable information. The objective of this study is to develop a geographic information system to help managing and mapping process of irrigation infrastructure, such as flood gate and water ways. This system also helps to manage all the irrigation area and infrastructure data by providing geological information, search, and managing database function. We developed a web application for system interactivities. We also work together with Dinas Pekerjaan Umum dan Penataan Ruang of Kabupaten Kubu Raya, as they are managing nearest irrigation land which available to be inspected for research. The system has been tested in a real-life case study. As a result, the system enhances the efficient management of irrigation area and infrastructure data. Users stated that this geographic information system has many benefits to irrigation area management., i.e, ensuring data authorization with user information when data is recorded, real time image capture for each irrigation infrastructure, and digital maps to gain a wide overview of irrigation area information on Kabupaten Kubu Raya.
\end{abstract}

Keywords: irrigation area, irrigation infrastructure, geographic information system

\section{INTRODUCTION}

Irrigation area is a land comprises with water from irrigation network consist of canals and construction to serve, share, deliver, use, and disposal of water throughout the area. It requires irrigation network management, a sequence of procedures, e.g. actions, maintains, and rehabilitation. The main purpose of irrigation process is to increases farmer's productivities by enhancing agriculture commodities. The development of irrigation infrastructure periodically is a must. Therefore, a reliable information is important to conduct the effective plan and management processes. A visualization of entire area along with the infrastructure may reducing the adversity of managing the entire infrastructure.

Indonesia will become a nation with lack of rice supply if there are no solution for water deficiency on their irrigation areas. Development of irrigation infrastructure with proper and quick investigation could be an alternative. One of the most reasonable solution is to conduct development phase implements innovation in technology (Pasandaran, 2016).

A policy to encourage consolidation of diversification agricultural commodities to build a balance between improvements of farmer's productivity and agricultural efficiency is necessary. One of the possible approaches is the development of irrigation area around the fields (Siregar, 2016).

The objective of this study is to develop a geographic information system to help managing and mapping process of irrigation infrastructure, such as flood gate and water ways. Each infrastructure is located on specific coordinates which recorded on a database managed by Dinas Pekerjaan Umum dan Penataan Ruang of Kabupaten Kubu Raya.

* Corresponding Author 
This system also helps to manage the irrigation area and infrastructure data by providing geological information, search function, and managing database function. We worked together with Dinas Pekerjaan Umum dan Penataan Ruang of Kabupaten Kubu Raya, as they are managing nearest irrigation area available to be inspected for research. The water quality on one of their irrigation area on Kecamatan Terentang is evidently appropriate for irrigation (Fitriadi, F., 2016). Also, agricultural commodities is one of their promising sector to be developed in future (Hajeri, H., et.al, 2015).

\section{LITERATURE REVIEW}

We reviewed a few previous works related to GIS. For example, an application of field mapping using remote sensing and GIS on an irrigation area in India (Nikam, B.R et.al, 2010), an Android application to map disasteraware villages of Gorontalo District (Pakaya .A, 2020), and effectiveness examination of suitable GIS implementation on land administration in Kaduna (Shekarau, J.A. \& Aliyu, M.A, 2019).

Furthermore, we alse reviewed other works related to GIS of agricultural fields, such as development of monitoring system for environmental conditions of agricultural fields using Arduino and Wireless Sensor Network (Sushanth, G. \& Sujatha, S, 2018), an information system of irrigation building on Rentang irrigation area (Ayuningtias, D. K, 2014), and a location reporting system for irrigation field officers using Android application (Sunaryo, B. et.al, 2019).

In addition to manages irrigation area information database, this system also serves as a Geographic Information System (GIS), a computer-based system capable of capturing, preparing, managing, saving, analizing, manipulating, and presenting georeference data (Huissman \& De By, 2009). The maps displayed on this system are built using Leaflet JS, an open source Javascript library for interactive digital map hosted on public server. It can be accessed using web browser. Leaflet uses World Geodetic System 1984 (WGS84) as the coordinate system consist of latitude and longitude variables (Derrough, 2013).

We developed a web application for system interactivities, using Rapid Application Development (RAD) methodology. It is a collection of techniques, procedures, and integrated device which supports and satisfy user requirements in a short period of time. The software changes continuously as more user feedbacks received during development (Daud et.al, 2010).

We collected irrigation infrastructure data from several irrigation area around Kabupaten Kubu Raya. This is a district located in western area of Provinsi Kalimantan Barat, Indoonesia. It has 9 sub-districts along with 50 irrigation areas, each consist of irrigation infrastructures.

\section{METHOD}

This research focused on managing and mapping the irrigation infrastructure. We start collecting data of irrigation area, such as coordinates, area code, restoration date, district, sub-district, and authority. We also collect irrigation infrastructure data, e.g. flood gate type, conditions, coordinates, length of water ways, and photos of each infrastructure. The collected data subsequently analyzed to design the Entity Relationship Diagram (ERD). It is a conceptual level of database design and at a higher level of abstraction (Byrne, B. M., \& Qureshi, Y. S., 2013). We aimed to develop a high-quality database design so it can easily be maintained and upgraded for future works. This diagram is depicted on Fig. 1.
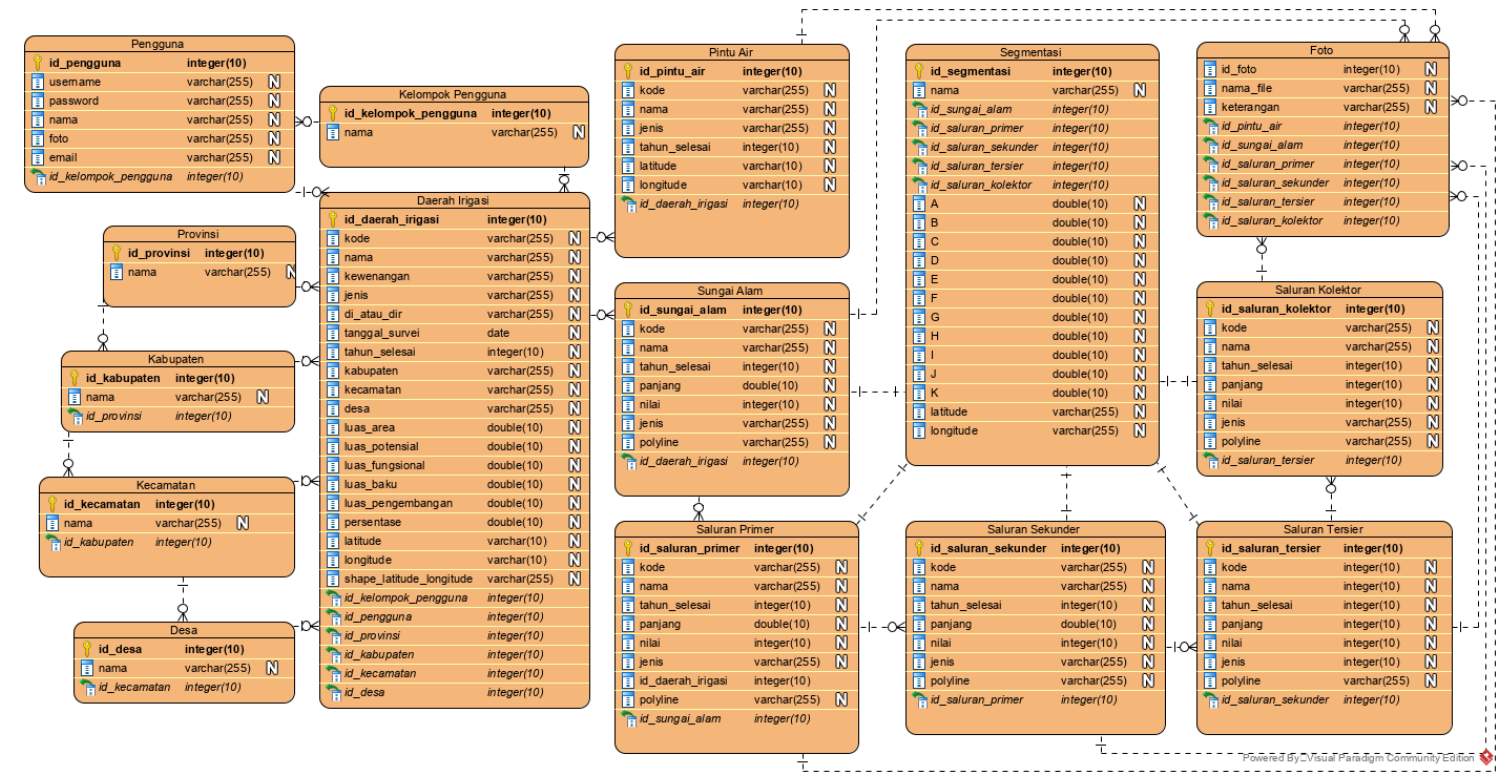

Fig. 1 Entity Relationship Diagram 
This system development phase requires feedback from authorized party, viz., Dinas Pekerjaan Umum dan Penataan Ruang Kabupaten Kubu Raya. In that case, it is necessary to set up boundaries between users with different level of authorization. We designed a Use Case Diagram depicted in Fig. 2 to cultivate these arrangements. Use Case Diagram is appropriate to be used as a draft for analyzing systems (Aleryani, A. Y., 2016).

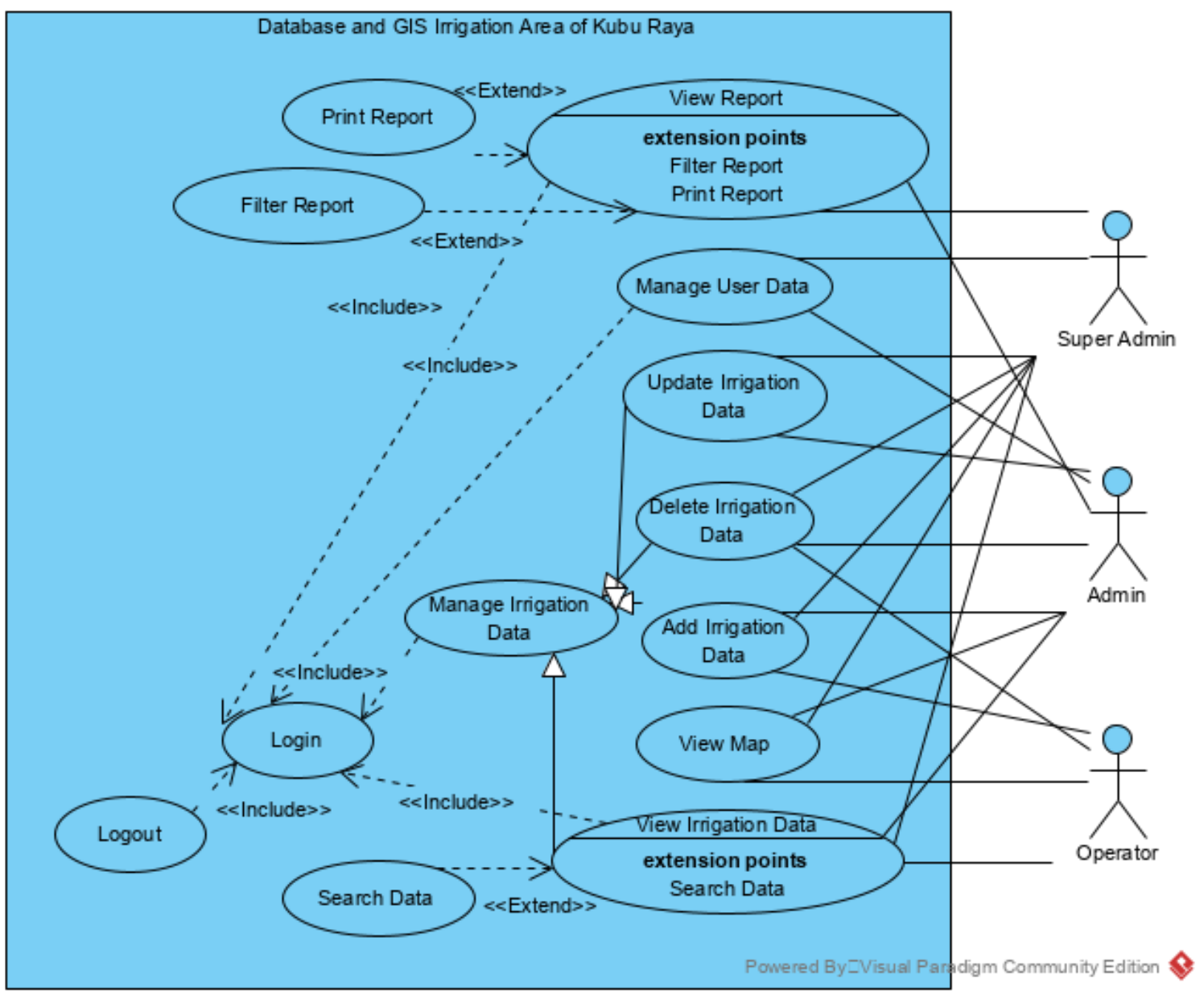

Fig. 2 Use Case Diagram

There are three levels of user, i.e. Super Admin, Admin, and Operator. Each of them has a different roles and permissions. For instance, an operator is the only user level unable to use reporting functionality unlike the other.

\section{RESULT}

This system is web-based so that we start by developing a web application and its database. We use PHP and Javascript to handle the user interface, also MySQL as the service to deploy the database.

Fig. 3 shows a table of irrigation area comprises irrigation area codes, and names. Users will be able to manage every irrigation infrastructure data using the buttons on each the rows.

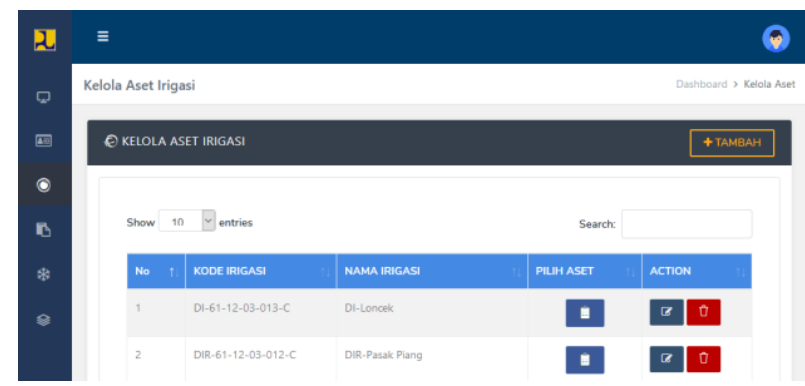

Fig. 3 Irrigation Area Dashboard

Fig. 4 depicts selected irrigation infrastructure information, i.e. flood gate. This page shows information in respect of locations, flood gate codes, names, and conditions. 


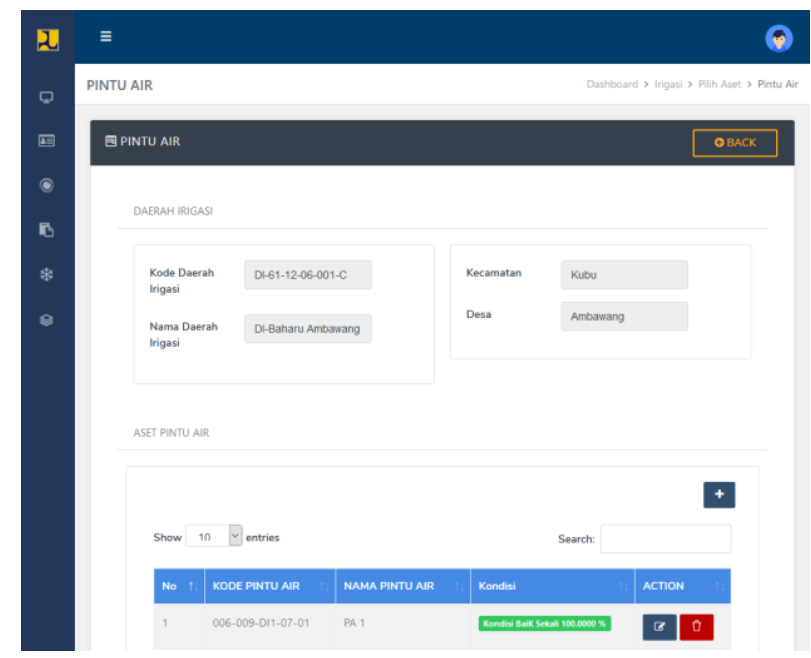

Fig. 4 Flood Gate Dashboard

Fig. 5 shows a map consist of polygons to indicate irrigation area, polylines for waterways, and a circle to denote flood gate. Users will be able to zoom in or out to show more details of the map, and search for certain irrigation infrastructures nearby.

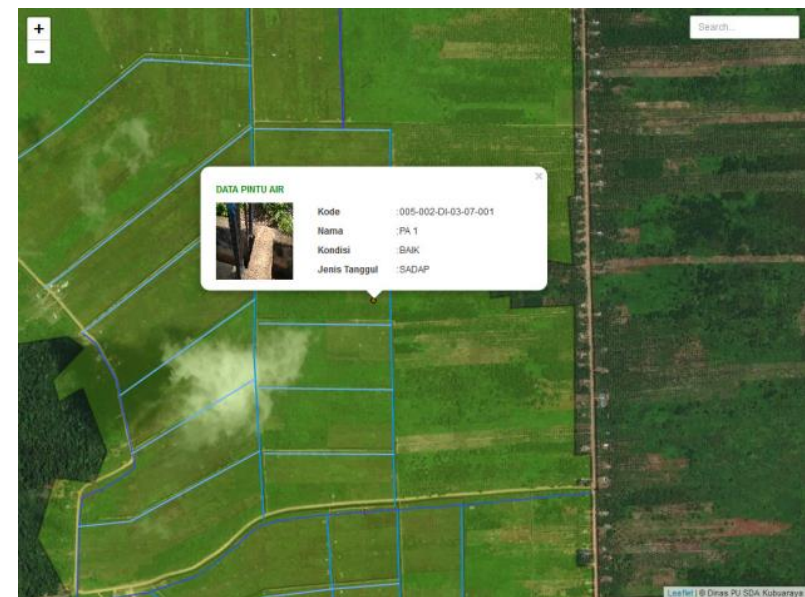

Fig. 5 Irrigation Area Map

Report shown on Fig. 5 are waterways informations, such as names, locations, codes, and conditions. Users may print this report as PDF files, if necessary.

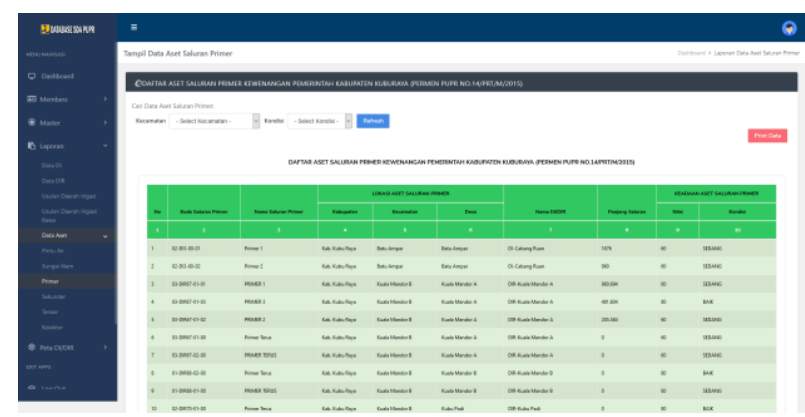

Fig. 5 Water Ways Report

To determine whether this system satisfies the user requirements, we used User Acceptance Test (UAS) method. The test is proposed to validate software against business requirements, which is the usability for managing and mapping of irrigation infrastructure by Dinas Pekerjaan Umum dan Penataan Ruang Kabupaten Kubu Raya. The choices for each statement on this test were structured using Likert format. There are five choices provided for every statements. The choices represents the degree of agreement, i.e. Strongly Agree (SA), Agree (A), Neutral (N), Disagree (D), and Strongly Disagree (SD). The results are shown in Table 1. The test concluded that there is a high satisfaction of users for the functionalities on this system. 
Table 1

User Acceptance Test

\begin{tabular}{|c|c|c|c|c|c|}
\hline Description & SD & D & $\mathrm{N}$ & A & SA \\
\hline Easy to navigate & & & $7 \%$ & $10 \%$ & $83 \%$ \\
\hline No missed data to managed & & & $6 \%$ & $6 \%$ & $88 \%$ \\
\hline Images load quickly & & & $22 \%$ & $22 \%$ & $56 \%$ \\
\hline Maps displayed correctly & & & $8 \%$ & $20 \%$ & $72 \%$ \\
\hline No authorized action occurred & & & & $7 \%$ & $93 \%$ \\
\hline
\end{tabular}

\section{DISCUSSION}

Our work has several differences from previous works as our system are built based on requirements from Dinas Pekerjaan Umum dan Penataan Ruang Kabupaten Kubu Raya. In consequence, the whole functionalities are designed to fulfill the requirements. We build a report page for users if they have to print the irrigation area report in PDF format. The maps displayed on this system are using geolocation data with WGS84 coordinate system as the latest revision of World Geodetic System (WGS), a standard for use in cartogrphy, geodesy, and satellite navigation. The three levels of users are set according to level of authority in Dinas Pekerjaan Umum dan Penataan Ruang Kabupaten Kubu Raya.

This research conducted to build a system that fully satisfy the user requirements. Therefore. a frequent visit to the irrigation area is required. As we permitted to conduct research on an irrigation area, which is a government property, it is necessary to follow the instruction from the authority. As a result, this research's system design is exemplary for other web developers who wants to build government apps in their project.

There are few limitations on this work, such as there are no functionality to track the operator's location when they send report. Also, the images captured using smartphone are stored without any compressing process. Hence, this system required a large storage space on the server. Also, we have to design an inelaborate user interface on our system since the users are immensely unfamiliar with technology.

Security is a crucial part on every application. In this research, we only used basic security system, i.e., XSS filtering security, which prevents any malicious Javascript code. Furthermore, this system requires a higher level of detection and prevention mechanism to prevent any access from unauthorized personnel in future.

\section{CONCLUSION}

Our goal is to develop a geographic information system to help managing and mapping process of irrigation infrastructure and also helps to manage all the irrigation area and infrastructure data by providing geological information, search, and managing database function. The result is a running web application which able to satisfy user requirements based on the results from UAT test. Maps displayed correctly using Leaflet JS on a web page, exposing brief information of irrigation infrastructures. Web application development process using RAD, sufficiently satisfy user requirements of this system. In order to build a running application for government, we found that one has to adjust the development process with the requirements discussed with the authority before starting the project. For example, in our matter, the authority are using Degrees Decimal Minutes (DDM) as the coordinate format on their database, while Leaflet JS requires Decimal Degrees (DD) as their input. The geographic information system are running satisfactory based on UAT test. It can manage irrigation infrastructure data while using digital maps to display geological information. Users also stated that this geographic information system has many benefits to irrigation area management., i.e, ensuring data authorization with user information when data is recorded, real time image capture for each irrigation infrastructure, and digital maps to gain a wide overview of irrigation area information on Kabupaten Kubu Raya. There is an opportunity to integrate this system with an Android application with an ability to monitor surveyor works and record data directly from devices.

\section{REFERENCES}

Pasandaran, E. (2016). Pengelolaan infrastruktur irigasi dalam kerangka ketahanan pangan nasional. Analisis Kebijakan Pertanian, 5(2), 126-149.

Siregar, M. (2016). Determinan Efisiensi Teknis Usahatani Padi di Lahan Sawah Irigasi. Jurnal Agro Ekonomi, 21(1), 72-96.

Fitriadi, F. Analisis Kualitas Air Pada Saluran Irigasi Untuk Kebutuhan Padi Sawah Di Desa Sungai Radak I Kecamatan Terentang Kabupaten Kubu Raya. Jurnal Sains Mahasiswa Pertanian, 5(1).

Hajeri, H., Yurisinthae, E., \& Dolorosa, E. (2015). Analisis Penentuan Sektor Unggulan Perekonomian di Kabupaten Kubu Raya. Jurnal Ekonomi Bisnis dan Kewirausahaan (JEBIK), 4(2), 253-269.

Nikam, B. R., Garg, V., Thakur, P. K., \& Aggarwal, S. P. (2020). Application of Remote Sensing and GIS in Performance Evaluation of Irrigation Project at Disaggregated Level. Journal of the Indian Society of Remote Sensing, 1-19. 
Pakaya, A. (2020). Sistem Informasi Geografis Lokasi Desa Tangguh Bencana (DESTANA) Berbasis Android Pada Badan Penanggulangan Bencana Daerah Kabupaten Gorontalo. JSAI (Journal Scientific and Applied Informatics), 3(1).

SHEKARAU, J. A., \& ALIYU, M. A. (2019). Effectiveness Of Geographical Information System On Land Administration In Kaduna Geographic Information Service (KADGIS).

Sushanth, G., \& Sujatha, S. (2018, March). IOT based smart agriculture system. In 2018 International Conference on Wireless Communications, Signal Processing and Networking (WiSPNET) (pp. 1-4). IEEE.

Ayuningtias, D. K. (2014, November). Visualization of condition irrigation building and canal using web GIS application. In 2014 The 1st International Conference on Information Technology, Computer, and Electrical Engineering (pp. 309-314). IEEE.

Sunaryo, B., Rusydi, M. I., Rusdi, J. F., Suriani, R., \& Daus, S. (2019). Sistem Pelacakan Lokasi Pelaporan Petugas Lapangan Irigasi Provinsi Sumatera Barat Berbasis GPS Smartphone dan WebGIS. Jurnal RESTI (Rekayasa Sistem dan Teknologi Informasi), 3(2), 271-281.

Huisman, O., \& De By, R. A. (2009). Principles of geographic information systems. ITC Educational Textbook Series, $1,17$.

Derrough, J. (2013). Instant Interactive Map Designs with Leaflet JavaScript Library How-to. Packt Publishing Ltd.

Daud, N. M. N., Bakar, N. A. A. A., \& Rusli, H. M. (2010, June). Implementing rapid application development (RAD) methodology in developing practical training application system. In 2010 International Symposium on Information Technology (Vol. 3, pp. 1664-1667). IEEE.

Byrne, B. M., \& Qureshi, Y. S. (2013). UML class diagram or entity relationship diagram? An object-relational conceptual impedance mismatch. In Proceedings of the 6th International Conference of Education, Research and Innovation (ICERI2013) Conference 18th-20th November 2013 (pp. 3594-3604).

Aleryani, A. Y. (2016). Comparative Study between Data Flow Diagram and Use Case Diagram. International Journal of Scientific and Research Publications, 6(3), 124-126. 